\title{
Necessity and Freedom in Ostrovsky's Thunder
}

\section{Irene Zohrab}

Alexander Ostrovsky (1823-1886) is regarded as the founder of Russian national theatre, while his tragedy Thunder (Groza) is a classic of Russian drama. ${ }^{1}$ Since its first performance on 16 November 1859 at the Moscow Maly Theatre, it has been one of the most frequently performed plays, as well as the most frequently published one (being a secondary school text in Russia). Thunder combines elements of traditional Greek tragedy with many innovative features. The play has inspired a variety of stage interpretations that have catapulted it into the realm of modern theatre foreshadowing "Chekhovian" drama associated with what has come to be known as "method acting." It is, perhaps, best known to audiences in the West as Katya Kabanova in the operatic version of Leos Janacek. ${ }^{2}$

The dramatic universe in Ostrovsky's tragedy Thunder is constructed on contradictions and divisions inherent in the society it depicts, while its dramatic tensions are generated by the cultural ambiguities embedded within the fabric of that society. Silhouetted against this background is the solitary figure of the tragic heroine, Catherine. Victimised for her "otherness" and eventually ostracised for having transgressed the norms of this community, she is driven to her tragic end to the accompaniment of thunder and lightning (groza), symbolising the superior powers of superhuman forces. ${ }^{3}$

Criticised for not adhering sufficiently closely to the norms of tragedy as set out in Aristotle's Poetics, Ostrovsky and his play were defended by Dobrolyubov in what was to become the most celebrated interpretation of Thunder: it views the merchant milieu

${ }^{1}$ For a copy of the tragedy currently in print, see Alexander Ostrovsky, The Storm, trans. Constance Garnett (Faber Finds, 2008).

2 John Tyrell, Leos Janacek: Katya Kabanova (Cambridge: Cambridge University Press, 2001); John Tyrrell, Janacek: Years of a Life, vol. 2 (1914-1928): Tsar of the Forests (London: Faber \& Faber, 2007). See also Charles Osborne, The Opera Lover's Companion (New Haven: Yale University Press, 2004), 186-93.

3 The symbolic and mytho-poetic elements in Thunder have recently been analysed by Vasilii Shchukin, "Zametki o mifopoetike "Grozy'," Voprosy literatury, no. 3, 2006. 
depicted in the play as a "Kingdom of Darkness," while the actions of the tragic heroine, including her suicide, are perceived as constituting a "Ray of Light in the Kingdom of Darkness.", Dobrolyubov's critical texts have become part of the canon of Russian writing, while Ostrovsky's play itself is regarded as a paradigm of Russian culture. Similarly, the tragic heroine Catherine has come to be regarded as the quintessence of native Russian womanhood. It can be argued that Ostrovsky and Dobrolyubov have influenced the social construction of the allsuffering female victim in Russian culture, set apart and destroyed for her elemental yearning for the unattainable and the maximalist expression of her will (volia). Thus Catherine the tragic heroine, a saintly sinner sacrificed and thereby redeemed, has come to be seen as a prototype of corporeal femininity and alterity to be aspired to.

\section{Binary Models in the Dynamics of Russian Culture}

As a cultural text Thunder has been constituted by the uniqueness of the social structure of "Holy Russia," with its values, traditions and beliefs, and its particular historical background. ${ }^{5}$ According to

\footnotetext{
${ }^{4}$ N. A. Dobrolyubov, "Realm of Darkness: The Works of A. Ostrovsky," and "A Ray of Light in the Realm of Darkness: The Thunderstorm. A Drama in Five Acts by A. N. Ostrovsky," in Selected Philosophical Essays, trans. J. Fineberg (Moscow: Foreign Languages Publishing House, 1956), 218-373 and 548-635. First published in Sovremennik, 1860, vol. 83, no. 10, okt, 233-92. See also: N. F. Pavlov, "Groza. Drama v 5-ti deistviiakh A N Ostrovskogo," Nashe vremia, 1860, no. 1, 17 ianv, 12-16; no. 4, 7 fevr, 62-64; here Pavlov accuses Ostrovsky of having written a play that is only fit to be performed at a country fair or showbooth (balagan). For a Selected Bibliography of works about Ostrovsky in English, see "Aleksandr Nikolaevich Ostrovskii 1823-1886. Dramatist," in Reference Guide to Russian Literature, ed. Neil Cornwell (London and Chicago: Fitzroy Dearborn, 1998), 606-07. For a comprehensive discussion of the play, see Richard Peace, "A. N. Ostrovsky's The Thunderstorm: The Dramatization of Conceptual Ambivalence," The Modern Language Review, vol. 84, no. 1, January 1989, 99-110.

5 A. N. Ostrovsky, Thunder, in Four Russian Plays, trans. and intro. Joshua Cooper (Harmondsworth: Penguin, 1972), 319-94. (Ostrovsky's tragedy has also been translated as The Storm and The Thunderstorm.) The following Russian text is used: A $N$ Ostrovskii. Polnoe sobranie sochinenii $v$ dvenadtsati tomakh, II
} 
the Russian critics J. Lotman and B. Uspenskij, culture may be understood in the widest sense of the word as non-hereditary collective memory expressed in a definite system of prescriptions and prohibitions. One specific feature of the regenerative mechanism within Russian culture is its fundamental polarity which is expressed in the dual character of its structure. Basic cultural values (ideological, political, and religious) are arranged in a "bipolar value field divided by a sharp line and without any neutral axiological zone" (unlike the pattern in Western culture, which includes a neutral zone). One of the most persistent oppositions contributing to the structure of Russian culture throughout its history is the opposition "old" ways- "new" ways, and there are many other oppositions of this type, including "Russia - the West," "Christianity_paganism," "true faith-false faith," "knowledge-ignorance" and "the social top-the social bottom."

A similar bipolar value field with oppositions of the type listed by Lotman between the "old" and the "new" is discernible in Thunder. On one side of this bipolar value field we have the socalled "Kingdom of Darkness" and its agents representing the "old" ways, "the social top," "ignorance," "tyranny," "compulsion" and "lack of awareness"; these are associated with authority, oppression and conservative forces. On the opposite side of this bipolar field we have the "Ray of Light in the Kingdom of Darkness" and its agents, representing the "new" ways, "the social bottom," "knowledge," "freedom," "awareness" and "victimage"; these are associated with the oppressed and the progressive who seek freedom and self-expression. On the metaphysical level these oppositions can be said to persist as those between reason and spontaneity, necessity and freedom, reality and the Ideal, matter and spirit or phenomena and noumena. All the main characters, as well as all the secondary ones in this essentially native Russian tragedy, can be grouped according to these binary value fields.

There are four distinct dimensions or worlds within which the tragedy Thunder operates. The first is the domestic context of the

(Moscow: Iskusstvo, 1974), 209-66. Hereafter all page references to the Russian text will follow the page references to the translated text in square brackets.

6 J. M. Lotman and B. A. Uspenskij, "The Role of Dual Models in the Dynamics of Russian Culture," in The Semiotics of Russian Culture (Ann Arbor: Dept. of Slavic Languages and Literatures, University of Michigan), 1984, 3-35. 
family circle within which the personal and psychological confrontations are developed. The second is the social context which serves to magnify these conflicts and confrontations, refract them amongst the numerous secondary characters and endow them with historical contingency. Both these dimensions are grounded within the human domain. The third dimension is that of nature wherein the River Volga symbolises freedom and rebirth, while the thunderstorm (groza), the dynamic central referent within the play, is a multivalent symbol of power and awe determined by the perspective through which it is being refracted. The conflicting forces in nature parallel the conflicting forces in the human world. The fourth is the cosmic dimension, outside space and time, though transmitted through the thunderstorm, lightning and other means, and associated with both the pre-Christian deities (such as the Slav god Perun, the counterpart of Zeus and Jupiter) and with the Christian tradition ( $\mathrm{St}$ Elijah, the saint associated with thunderstorms). By focusing on the third and fourth dimension of the play Ostrovsky has drawn on the rich source of Slavonic and universal myths, while at the same time helping in the creation of new cultural myths.

The point at which Catherine suffers and dies is the point at which these worlds or dimensions intersect. In that sense her role within the structure of Thunder is similar to that of the Greek tragic hero, who is regarded as being both an individual caught in a moral conflict and a symbolic element within a complex socio-religious structure. The Greek tragic hero links the worlds of the human and divine, the natural and the supernatural. He carries the "linear flow of action and is a constellation of patterns present simultaneously in all parts of the action." ${ }^{7}$ However, unlike Catherine, who is a simple girl from the emerging merchant class of former peasants, the Greek tragic hero is more often than not a man and a king (Sophocles' Oedipus, Aeschylus' Agamemnon, or Euripides' Pentheus). In that role he concentrates in himself "the crisis in relations between the human, natural, and supernatural worlds which forms the starting point for the tragic action."

7 Charles Segal, Interpreting Greek Tragedy: Myth, Poetry, Text (Ithaca and London: Cornell University Press, 1986), 29.

${ }^{8}$ Ibid. 


\section{"Holy Russia"—A Religious-Social Idea}

Although some of the social and psychological categories of Greek tragedy do not correspond to those of Russia of the mid-nineteenth century as represented in Thunder, there are nevertheless a number of points of convergence. For one thing, the dramatic universe in Greek tragedy is constructed on contradictions as indeed is the case in Ostrovsky's tragedy; and for another the human world in "Holy Russia" is inextricably tied up with the natural world and the divine. In fact, of all European countries only Russia called herself "Holy." Although the last European society to adopt Christianity at the end of the tenth century she considered herself the youngest and most favourite child of Christ. This is reflected in her language where, for instance, the Russian word for peasant is "Christian" (krest'ianin). With the fall of Rome and later of Byzantine Constantinople, which was interpreted as a sign of divine wrath, Russia anointed herself as the "Third Rome." Thus "Moscow the Third Rome" became the seat of Tsardom, its ideology subsequently summed up in the slogan "Autocracy, Orthodoxy and Nationality." Her ruler was "God-chosen, God-beloved, Godhonoured and God-enlightened, the God-glorified pilgrim of God on the righteous path of God's appointed law."9 St John Chrysostom had declared that if men resist the authority of Caesar (the Tsar), they resist God's commandment. God had set Tsars on their thrones in His own place, and similarly the landowner was responsible for and had authority over his peasants and the head of the household over his dependents. Awesome majesty (groza) was the most important attribute of power: "A tsar without groza is like a steed without a bridle." 10 Within this patriarchal hierarchy the person in authority was responsible for ensuring that order prevailed and the official ideology was propagated. Eventually this led to an insoluble conflict between the ideal of pious life in Christ and the necessities of temporal government: the "eternal tragic conflict between the personal and the social conception of Christianity - the personal conception which demands renunciation

9 A. Popov, Istoriko-literaturnoe obozrenie polemicheskoi literatury protiv latin'ian (Moscow, 1875), 395. Quoted in Alexander V. Soloviev, Holy Russia: The History of a Religious-Social Idea ('S-Gravenhage, 1959), 16.

${ }^{10}$ A Russian rhymed saying or proverb: "Tsar' bez grozy, chto kon' bez uzdy." 
of all evil, of all force, and the social conception, which wishes to destroy great evil by lesser evil, and from this point of view attempts to justify both compulsion and war, and even capital punishment." ${ }^{\prime 11}$ In the reign of the pious, but cruel and deranged Ivan the Terrible (Grozny) this conflict assumed fantastical proportions, so that by the time of Peter the Great, the Tsar was regarded in terms of the Antichrist because of the godless forms in which his authority was cast.

The domestic tyrants in Thunder such as Mrs Kabanova and Dikoy, the heads of their respective households who uphold tradition, the ideology of the church and righteousness, also resort to compulsion to maintain order. They do so "in the name of godliness" (322 [210]) and expect total submission from their dependents. They feel justified in doing so, since they are serving a higher cause. This is pointed out by Kudryash, an inhabitant of the town of Kalinin where Thunder is set within a minute or so of the curtain rising on act 1 (321-22 [210-11]). The compulsion and violence at the top has produced a society wherein the strong are "cruel," "abusive" and act as a group like a pack of wolfhounds, who could "eat" or "swallow" one "down alive" (326-28 [21415]).

The English-speaking reader may have noted by now the repetition of the word groza, the word in the title of Ostrovsky's tragedy translated into English as The Storm or Thunder. The same word also denotes dread, threat, awesome power and so on (as indicated in its use in the adjectival form to describe the most feared Tsar, Ivan the Terrible (Grozny). There are numerous references to groza in the text of the play in its noun form, as well as in its adjectival and verbal forms. In addition, there is a great deal of figurative language, including some alliteration and assonance that echoes the central referent, the storm. The resulting ambiguity relating to meaning extends to the entire fabric of the play, encompassing its dramatic and psychological levels. This lack of fixety or stable meaning is subsumed into the speeches of the characters, and extends to their identities, such as the "self" of the tragic heroine, which will be discussed later.

Thus, in their widest terms the conflicts and contradictions in Thunder must be considered in the context of the idea of "Holy

11 Soloviev (n. 9 above), 25. 
Russia" with its messianic role of spreading harmony, an idea that in actual practice turned into tyranny and oppression. It underscores one of the main themes in Thunder, that of the conflict between freedom and compulsion, and determines the crucial role that religion plays in the play, perceived as it is from a variety of perspectives. The world of nature and the seasons, which possessed its own divinities so important in agricultural Russia of the preChristian era (later to be subsumed into folklore and Russian Orthodox Christianity), serves as a backdrop to the dominant socio-domestic dimension of Thunder.

\section{Thunder's Socio-Domestic World: The Realistic Convention}

At its most explicit level, however, Thunder was written within the realistic convention; it was intended to be viewed and appreciated by an unsophisticated Russian audience of the mid-nineteenth century. One of Ostrovsky's aims was to create an illusion of life and indeed, his plays came to be described as "plays of life." The language used is deliberately colloquial, spoken rather than written or literary language, characteristic of the merchant milieu and containing colourful native idioms and concepts expressive of indigenous creativity. ${ }^{12}$ Thunder with its realistic stagecraft is a forerunner of the movement that culminated in the triumph of realism and naturalism on stage, a modern poetic expressive of

12 Ostrovsky viewed the production of language as an organically creative process. Language was not an "invention" (sochinenie), but a "revelation" (tvorenie). See Ostrovskii (n. 5 above), vol. 10, 456. In the process of writing his plays he would always say the lines out loud and put himself in the place of the actor playing the part. This was consistent with his view that dramatic style is primarily theatrical in character. The "form" (sklad) of a dramatic idea is manifested as the "tone" of speech articulated on stage. The poetic, colloquial language of his merchant plays is akin to the language used by Irish dramatists such as Synge and O'Casey. The reason why Ostrovsky's plays have not been produced with success on the English stage is in large part due to the losses that have been incurred in their translation. See also Irene Zohrab, "Problems of Translation: The Plays of A. N. Ostrovsky in English," Melbourne Slavonic Studies (now Australian Slavonic and East European Studies), no. 16 (1992): 4386. 
modern concerns. ${ }^{13}$ It is a combination of two kinds of drama that were to dominate the European stage for the next one hundred years, namely "naturalistic drama" with its emphasis on external social conditions that were responsible for the hero's misfortune and "bourgeois tragedy," wherein the hero was caught in an insoluble moral dilemma because he (more often than "she") had transgressed some element of accepted moral conduct.

The audience is alerted to the socio-domestic world of Thunder as soon as the curtain rises on a setting of a public park in a provincial town Kalinov on the high bank of the Volga; across the Volga there is a view of the surrounding countryside. It is summer in pre-Emancipation Imperial Russia of the late $1850 \mathrm{~s}^{14}$ and a cross-section of the citizens of Kalinov are introduced, including all the main characters; the basic conflicts are engaged and the tragic denouement is foreshadowed by the impending storm and the oracle-like prophecies of the "half-mad old Lady with Two Footmen" (338 [223-24]). In act 2, the only act set indoors, the focus narrows on the claustrophobic household of one family, the Kabanovs. Catherine (whose name means "pure"), married to young Tikhon Kabanov (whose first name means "quiet"), is tempted to make the fateful decision to meet with the newcomer from the city, Boris Dikoy, the object of her desire. The secondary exposition of act 3, scene 1 is set in the street outside the Kabanov residence. The agents of the repressive forces in the play, the wealthy widow Mrs Kabanova (whose name means "wild sow") and the merchant Saul Dikoy, a person of consequence in the town (whose name means "savage" or "insane"), provide further evidence of their despotic power based on fear and coercion within this socio-domestic territory. In scene 2 the foursome of young lovers meet secretly at night down by the overgrown ravine by the

13 T. S. Eliot, Selected Essays, $3^{\text {rd }}$ enlarged edition (London: Faber and Faber, 1951), 111, describes unlimited realism as the "great vice of [...] drama," which has "no form to arrest, so to speak, the flow of spirit at any particular point before it expands and ends its course in the desert of exact likeness to the reality which is perceived by the most commonplace mind." It is pertinent to note that Eliot regarded realism as limiting, as did some Russian writers of the second half of the nineteenth century. See also Irene Zohrab, 'Ostrovskii i Dostoevskii,' in $F M$ Dostoevskii. Materialy i issledovaniia (Leningrad: Nauka, 1988), 107-25.

14 The peasants were emancipated in Russia in 1861, two years after the appearance of Thunder. 
Volga where Catherine's extra-marital affair with Boris Dikoy takes place. This scene is replete with symbolic overtones while the songs sung by Kudryash foreshadow the tragic outcome. The tragic climax is precipitated in act 4, again a public setting outside a disused church in a vaulted gallery with mosaics of the fires of Gehenna, beyond its arches a riverbank and a view of the Volga. Here Catherine's public confession of her transgression takes place, hastened by the mad Lady with the Two Footmen and echoed by thunder and lightning. The denouement is played out in act 5 which has the same public setting as act 1 (except that it is now twilight) endowing the action with a sense of circularity and inevitability. The distraught Catherine meditates on death, bids farewell to Boris and to life. Her body is recovered from the Volga by some inhabitants of Kalinov and by the enlightened Kuligin (a "self-taught scientist" who believes in the beauty of nature and the spiritual) who tells her oppressors: "Her body is here, take it, but her soul is not yours now; it is now before the Judge, Who is more merciful than ye" (390 [265]).

\section{Catherine as Victim and Scapegoat}

Catherine can be seen as the proverbial victim of the society depicted, metaphorically "sacrificed" because of her "otherness." Catherine's difference from the others is established from the outset; she is therefore suspect within that community and someone to be controlled. Within the paternalistic structure of that society the ultimate form of authority is punishment by exclusion, and the marginalisation and erosion of her humanity. Her instinctive, even intuitive, resistance is understandable to the spectator and within the world of this tragedy it is suggested as being ethically justifiable. Her attempts to protect her alterity and difference have a curiously contemporary resonance, since in the post-modern world "otherness" is something to be protected. ${ }^{15}$

\footnotetext{
${ }^{15}$ Many post-structuralist and post-modern thinkers have been anti-foundationalist in outlook, challenging the validity of networks of power relations operating in and defining a given field. Thus the "other" is often either collectively or individually the negative opposition in deconstructive discourse. See the works of Michel Foucault, Jacques Lacan, Jacques Derrida, J. F. Lyotard, and so on.
} 
Her difference is established right from the outset in the expositional section of the play when her sister-in-law, Barbara, who knows her perhaps better than any other character, describes her as being mudrenaia (and later chudnaia), translated in RussianEnglish dictionaries as "strange, queer, odd, difficult, abstruse, complicated" and "odd, strange, queer, funny" respectively. In Joshua Cooper's translation for Penguin the sentence is rendered as "Good heavens, you're a hard one to understand!" In the very first translation into English, Constance Garnett renders the sentence as: "You are such a fantastical creature, God bless you!" (42). As the tension rises in the play so does the perception of Catherine's alterity: "She's simply out of her mind"; "There's a crazy look in her eyes (kak $i$ pomeshennoi)"; "We've got a queer sort of girl there (chudnaia). Anything can happen with her" (376 [253]). The critic Dobrolyubov, who saw the first production of the play, wrote of Catherine: "In the opinion of those around her, she is queer and crazy (strannaia, sumasbrodnaia), that is because she cannot accept their views and inclinations. She takes materials from them because she has no other source, but she does not take their conclusions; she seeks her own, and often arrives at something entirely different from what they are content with." 16

According to the popular understanding of the time, Catherine's difference, akin to craziness, was an element perceived as uncontrollable. Therefore, as a marker of her otherness it had to be isolated and controlled. In addition, signs of madness or difference were closely related to signs of social inferiority. ${ }^{17}$ In her dialogues with Barbara (which serve to explain Catherine's nature and her position within the merchant milieu) Catherine's inability to dissemble, deceive, or act under compulsion, is revealed; both these attributes are necessary for ensuring survival in the "Kingdom of Darkness." It could be argued that the lack of these attributes constitutes her "fatal flaw": her inability and unwillingness to conform to the rules and expectations of her community. She is spontaneous by nature, propelled by her senses and emotions, hence instinctive and intuitive in relation to her

\footnotetext{
${ }^{16}$ Dobrolyubov (n. 4, above), 611.

17 Sander L. Gilman, Disease and Representation: Images of Illness from Madness to AIDS (Ithaca and London: Cornell University Press, 1988), chap. 1. (Michel Foucault, the cultural historian and critic, has also discussed the representation and suppression of disease.)
} 
actions. In accordance with her nature she falls victim to her libidinal desires that culminate in her non-resistance to sexual passion (significantly, the object of her desire, Boris, is himself an "outsider" in this merchant community, a new arrival from Moscow and the only character in the play dressed in urban Western fashion):

Catherine: I can't be a deceiver; I can't hide things.

Barbara: Well, but you know you can't get along without deception; remember where you are living. That's what holds the whole of our home together. I usen't [sic] to be a deceiver, but I learned how when I had to.

[...] Good Heavens, you're a hard one to understand! What I say is, do what you want to do, but mind you keep it dark.

Catherine: I won't have that! Besides, what's the good? I'd better stick it as long as I can.

Barbara: But suppose you can't stick it out, what'll you do then?

Catherine: What will I do?

Barbara: Yes, what'll you do?

Catherine: When I want to do something, I'll go straight out and do it.

Barbara: Try that here, and they'll eat you.

Catherine: What's that to me? I'll go away. I'll vanish.

Barbara: Where to? You're a married woman.

Catherine: Ah, Barbara dear, you don't know what I can be like! Please God, of course, it won't come to that, but if I get to really loathe this place, no power on earth will stop me. I'll jump out of the window. I'll chuck myself into the Volga. If I don't want to live here I won't, I don't care what you do to me! (Silence.)

$$
\text { (344-45 [228-29]) }
$$

It has been demonstrated by cultural critics that the victimage mechanism underpinned by sacrifice is a driving force of culture.

${ }^{18}$ See René Girard, Violence and the Sacred, trans. Patrick Gregory (Baltimore and London: The Johns Hopkins University Press, 1977); Things Hidden since the Foundation of the World, trans. Stephen Bann and Michael Metteer (Stanford: Stanford University Press, 1987); Job the Victim of his People, trans. Yvonne Freccero (Stanford: Stanford University Press, 1987). See also Walter Burkert, Homo necans: The anthropology of ancient Greek sacrificial ritual and myth, trans. Peter Bing (Berkeley: University of California Press, 1983) and René Girard 
According to René Girard, the scapegoat or the victim of society safeguards the unity of his community through his suffering: "In any area of existence or behaviour abnormality may function as a criterion for selecting those to be persecuted. For example, there is such a thing as social abnormality; here the average defines the norm [...] Extreme characteristics ultimately attract collective destruction at some time or other." include physical criteria, such as sickness or madness; moral criteria, such as extreme vice or virtue; gender- and age-related criteria, such as the weakness of women or young people; social criteria ("every individual who has difficulty adapting, someone from another country or state, [...] even simply the latest arrival"). ${ }^{20}$ In the chapter "Stereotypes of Persecution" Girard maintains that "ultimately, the persecutors always convince themselves [...] that even a single individual, despite his relative weakness, is extremely harmful to the whole society." 21 It should be noted that attempts have been made to apply Girard's theory of generative scapegoating to the scapegoat mechanism operating in Greek tragedy and known as pharmakos. ${ }^{22}$

Girard also looks at examples of scapegoating wherein victims went to their deaths willingly, as is the case with Catherine in Thunder, and concludes that they are part of the same pattern. "The sacrifice of the victim is presented to us as an act of free will, a self-sacrifice, but a subtle element of constraint eats away at that freedom. $" 23$ It is this element of constraint that is decisive. (Curiously, he cites Stalinist Russia as one example where victims

and Walter Burkert, Violent Origins, ed. Robert G. Hamerton-Kelly (Stanford: Stanford University Press, 1987).

19 René Girard, The Scapegoat (Baltimore: The Johns Hopkins University Press, 1986), 18.

${ }^{20}$ Ibid., 18-19.

21 Ibid., 15.

${ }^{22}$ See Jean-Pierre Vernant, "Ambiguity and Reversal: On the Enigmatic Structure of Oedipus Rex," in Jean-Pierre Vernant and Pierre Vidal-Naquet, Myth and Tragedy in Ancient Greece, trans. Janet Lloyd (New York: Zone Books, 1988), 113-40; and Robin N. Mitchell-Boyask, "Dramatic Scapegoating: On the Uses and Abuses of Girard and Shakespearean Criticism," in Tragedy and the Tragic: Greek Theatre and Beyond, ed. M. S. Silk (Oxford: Clarendon Press, 1996), 42637.

${ }^{23}$ Girard (n. 19 above), 62. 
confessed to far more than was asked of them.) Girard interprets this as a form of "mimetic collaboration" of victims with their executioners, "mimesis" being according to his definition "the conflict that arises when human rivals compete to differentiate themselves from each other, yet succeed only in becoming more and more alike." 24

This may not be the place for delving into the complexities of Girard's pursuit of a general theory of religion and culture that accounts for the social function of ritual and "original acts of group violence" that are resolved by the scapegoating mechanism. However, the fact remains that, according to historical evidence, in "Holy Russia" certain agents of the "Old Testament" style of religion (later to be supplanted, it can be argued, by the role of ideology in Stalinist Soviet Russia) did resort to the production of persecution and violence which often resolved itself by means of the scapegoating mechanism, often with the apparently willing participation of its victims. An important psychological dynamic within such a society was fear, often produced through intimidation or emotional blackmail, and feelings of guilt engendered in its victims. Fear pervades the world of Thunder, fear experienced by both the oppressors and the oppressed. For example, Mrs Kabanova, the samodur and tyrannical head of the household, who incites fear in others, also experiences feelings of fear herself. When alone, she expresses fear and foreboding about change and the future: "But there you are; old customs are dying out. What will happen when the old people die off, how the world is going to carry on, I don't know. But there's one good thing, and that is that I shan't see any of it" (351 [233]). At the beginning of act 3, scene 1 the old pilgrim Feklusha invokes fear when she tells Mrs Kabanova that the end of the world is coming:

Feklusha: It's the end of time, Mrs Kabanova my dear, the end. By all the signs it is the end. In your town you still have the holy calm of heaven, but my dear in other towns it's just pandemonium. Uproar, tearing around and incessant travelling! ... Oh but my dear! Pray God you may never come to such an extremity of misfortune ... Grievous times, Mrs Kabanova, my dear, grievous times. And now time itself has begun to dwindle

${ }^{24}$ Ibid., 64. 
away ... [...] Days and hours seem to be just the same, but time, for our sins, is getting shorter and shorter. That's what clever people say.

Mrs Kabanova: And there'll be worse than that, my dear.

Feklusha: If only we don't live to see it.

Mrs Kabanova: Maybe we shall. (354-56 [236-37])

At the same time Mrs Kabanova tries to intimidate and implant feelings of obedience and fear in her daughter-in-law Catherine and her son Tikhon by invoking custom, tradition and godliness. When Tikhon manages to get away from his mother's presence he compares this to not having a constant source of "dread" (groza) like the thunderstorm hanging over him: "... a man would run away from the sweetest wife in the world to escape from this slavery [...] I know now that for a fortnight there's going to be no thunder hanging over me, and no shackles on my legs [...]" (348 [231]).

The repeated appearances of the Half Mad Lady with Two Footmen dressed in black and thumping her stick are intended to create an atmosphere of doom and fear. Her enigmatic language and prophecies are akin to the oracular pronouncements in Greek tragedy. At the end of act 1 she strikes fear and guilt in Catherine by threatening that beauty leads to destruction: "That is where beauty leads. [She points to the Volga.] Down there, down there, right down in the deep water! [Barbara smiles.] What are you laughing at? You mustn't enjoy yourselves. [She thumps her stick.] You shall all burn in unquenchable fire. You shall all boil in everlasting pitch. [Going away] Away down there, that's where beauty leads!" (338 [223-24]). The intrepid Barbara points out that the Lady also threatens other people in the town like thunder (grozit) and shakes her stick at them. The long speech by the Half Mad Lady with Two Footmen at the end of act 4 (379-80 [256]) precipitates Catherine's feelings of guilt to be poured out in a public confession:

The Lady: Hiding are you? It's no good hiding! You're afraid, by the look of it; you don't want to die! You want to go living! Of course she does; do you see now what a beauty she is? Ha Ha Ha! Beauty! You pray to God to take away that beauty! Beauty, you know, is the ruination of us! When you have destroyed yourself and seduced others to their ruin, then let you be 
rejoicing in your beauty! Many and many are the people that you will lead into sin! [...] And who will be answerable for it? You will have to answer for it all. You had best put that beauty of yours down into deep water! And quickly, quickly! [Catherine hides.]

Where are you hiding, you silly creature? You can't get away from God! [Clap of Thunder.]

You shall all burn in unquenchable fire! [Exit.]

Catherine: Oh, I'm dying!

Barbara: Now, really, what are you tormenting yourself for! Kneel over there, and say a prayer and you'll feel better.

[Catherine goes over to the wall and kneels down, then quickly jumps up.]

Catherine: Oh! It's Hell, it's Hell, it's the fires of Gehenna!

At this point Catherine had inadvertently seen the antique religious frescoes of the fires of Gehenna on the wall of the disused church where act 4 is set. At the beginning of this act various passers-by had already pointed out the significance of these fearinspiring paintings, depicting a time when misfortune had fallen upon the populace "out of the sky" (371-72 [250]). This fear is further fanned when the tyrannical Dikoy, the samodur, refuses to listen to the enlightened advice of Kuligin to put up lightning conductors to control the damage caused by thunder and lightning: "Thunder is sent to punish us, to make us think what we're doing, and you, Lord forgive you, want to protect yourself with a lot of rods and stakes. Are you a heathen, or what? Are you a heathen? Tell me, is that it? A heathen?" (374 [252])

The speeches of the Half Mad Lady with Two Footmen are also symbolic of the forces that hinder, in the name of authoritarian norms of conduct, the free expression or production of Catherine's desire and libidinal energy (especially when viewed in the postmodern context of the "desiring machine" in the terminology of Deleuze and Guattari.) ${ }^{25}$ Yet human sexuality has been shown to shape and focus on the image of the self. From the perspective of

25 Gilles Deleuze and Félix Guattari, Anti-Oedipus: Capitalism and Schizophrenia, trans. Robert Hurley et al. (Minneapolis: University of Minnesota Press, 1983), chap. 1, and A Thousand Plateaus: Capitalism and Schizophrenia, trans. Brian Massumi (London: Continuum, 2004). 
feminist critics the emphasis that the Half Mad Lady places on Catherine's beauty and her body, that is her corporeality in general, justifies a reading that displaces the centrality of Catherine's mind, psyche, interior or consciousness/subconsciousness, and focuses instead on a reconfiguration of the body. Catherine, the corporeal subject, is capable of initiating desire and responding to desire because of her senses and perceptions. According to feminist criticism the libido "emanates from the structure of sensibility, a function and effect of intentionality, of the integrated union of affectivity, motility, and perception." 26 Merleau-Ponty in The Phenomenology of Perception notes that "the senses communicate with each other [...] The sight of sounds and the hearing of colors come about in the same way as the unity of the gaze through two eyes: in so far as my body is not a collection of adjacent organs, but a synergic system, all the functions of which are exercised and linked together in the general action of being in the world, in so far as it is the congealed face of existence."27

Catherine's speeches include many intimations of sensations, establishing her as a highly sensory perceiving subject, that is a corporeal subject. Not only is her waking life dominated by her senses, but even memory for her consists almost exclusively of retentions of sensations. Her dreams are full of sensations and so are her day-dreams and her imagination. She repeatedly hears or imagines she hears voices or singing (336-37, 386 [221-22, 260]), whispering in her ear (336 [221]) noises in her head (386 [260]), the cooing of pigeons (337 [222]), invisible voices singing (336 [222]), angels singing (335 [221]), the singing of birds (389 [263]). She is sensitive to the fragrance of flowers (389 [263]), the smell of cypress wood (336 [222]). She visualises or responds to colours, whether of flowers, wonderful gardens, golden churches $(336,389$ [221-22, 263]) or of lights. She is sensitive to touch, whether it is the warmth of the sun, the moistness of rain or the softness of grass (389 [263]), and her imagination can conjure up sensations of being pushed or held in a "hot embrace" or being hemmed in or physically restricted (336-37, 387 [221-23, 262]); she feels her heart is "ripped and torn," or it "aches" and so on $(380,387$ [257,

\footnotetext{
${ }^{26}$ Elizabeth Grosz, Volatile Bodies: Toward a Corporeal Feminism (Sydney: Allen \& Unwin, 1994), 109.

27 M. Merleau-Ponty, The Phenomenology of Perception, trans. Colin Smith (London: Routledge \& Kegan Paul, 1962), 232-33.
} 
261]). Many of these sensations are associated with her early life at home and with her church:

On a sunny day, a sort of pillar of light used to come down from the dome, with clouds of smoke floating in the light, and I used to see angels flying and singing in the pillar of light [...] Such dreams I used to have, Barbara dear, such dreams! Either it was golden churches, or else some kind of wonderful gardens; and all the time there were invisible voices singing, and there was a smell of cypress-wood, and there were hills and trees, only they weren't like ordinary ones, but like the ones painted on the icons. Or else I seemed to be flying and flying through the air. (335-36 [221-22])

In addition to the usual five sense receptors, Catherine is also highly responsive to the kinetic sense, that is to motility or movement, speed or motion. She revels in the sense of unfettered movement and associates it with a sense of freedom and volition. That is why she repeatedly imagines herself flying through the air like a bird or a butterfly, or wishes to be carried away by rough winds. She remembers floating down the swift waters of the Volga in a boat and wishes to do so again, or to ride in a troika, a threehorse carriage. She dreams of flying through the air and in her waking moments almost simulates doing so. The denial of her senses, her body, her corporeality, aligned to her awakening passion for Boris, is a denial of the flux and flow of life as she knows it. In the course of the tragedy Catherine mourns for the loss of her idealised innocent early life with its dreams and aspirations.

Over and above her sense perceptions Catherine is also a highly intuitive subject. According to contemporary research into cognition it has been found that intuition shares certain properties with the creative process and is grouped with dreams and subliminal perception. Intuitive subjects commonly show a level of "high anxiety and excitability" and are also prone to "risk-taking"; like creative subjects they are prone to social and personal eccentricities. ${ }^{28}$ They demonstrate what is referred to as "global perception," a greater, more holistic grasp of a particular field of knowledge than non-intuitive subjects whose habits of thought are

28 Tony Bastick, Intuition: How We Think and Act (Chichester and New York: Wiley, 1982), 27, and see 168-70. 
"resistant to change" and who perceive the world in terms of "majority rules." $"$ At the same time intuitive thinkers are able to reach a conclusion "on the basis of little information which is normally reached on the basis of significantly more information." $" 30$ Otherwise researchers have found the same personality correlates for intuitive thinking as have been found elsewhere for creativity, namely tolerance of ambiguity. (Pressures of space preclude one from demonstrating that Catherine's personality fits the above definitions of an intuitive subject and enlarging on its implications in relation to the ambiguities embedded in the text of Thunder.) However, in Thunder these characteristics of Catherine's are presented as also being part of her femininity and a marker of her "otherness," which makes them suspect within her social community. Thus Catherine is different because she is too much like a woman; she is creative, intuitive, sensual and in addition possesses a preponderance of what are often perceived as negative feminine characteristics: she is emotional and not rational, she is unpredictable and changeable, she is inconsistent and therefore unreliable, and so on.

As she comes to be bullied, excluded and victimised in the name of authoritarian norms of conduct wherein her body or corporeality is viewed as an object of coercion and control, she is forced to either repress her own nature and corporeality, or to find some other means of resolution. Finally, she is driven to recognise her alterity and corporeality as being sinful, polluted and therefore repellent. This is akin to what Julia Kristeva has termed an act of "abjection," and is expressed in Catherine's public confession of her wrong-doing in act $4 .{ }^{31}$ It is instrumental in "pushing her over the edge," as her sense of self finally disintegrates. Her expiatory suicide (arguably akin in some respects to the expulsion of the pharmakos in the Greek tradition) is intended to produce a sense of pathos, provoking pity and fear in the audience. Catherine's disintegration is reflected in the structure of her speeches and soliloquies which become progressively more disjointed, punctuated by pauses, unfinished sentences and detailed stage

${ }^{29}$ Ibid., 349-50.

30 M. R. Westcott and J. H. Ranzoni, "Correlates of intuitive thinking," Psychological Reports, no. 12, 1963. Quoted in Bastick (n. 28 above), 349-50.

31 Julia Kristeva, Powers of Horror: An Essay in Abjection (New York: Columbia University Press, 1982). 
directions involving a great deal of frenetic movement as well as verbal communication.

\section{Multiple Points of View and Resultant Ambiguity}

Catherine's sense perceptions are aligned to her perception of religion. Although brought up in the same tradition of the Russian Orthodox Church as the other characters associated with the church and religion, such as Mrs Kabanova and the pilgrim Feklusha, Catherine's relationship with and understanding of the church is entirely different from theirs. This too sets her apart from the others. It is typical of Ostrovsky to set up alternative perspectives or multiple points of view through which the world within the play is perceived. Thus Catherine perceives religion and the Church as a vehicle of freedom and love. She associates it with her nostalgically idyllic memories of childhood innocence and the awakening of her senses. However, in Mrs Kabanova's household religion is used as a means of reinforcing repression, punishment and pain. Catherine associates religion with wide open spaces and a sense of movement and freedom, while in Mrs Kabanova's house religion is associated with images of confinement, walls, locks, the grinding of steel and shackles. The pilgrim Feklusha reinforces the latter perception of religion, while the enlightened Kuligin reinforces Catherine's perception of religion and links it up with the natural world and beauty. Scenes featuring these respective perspectives follow each other in sequence, that is they are designed to deliberately force the audience to become more aware-to lift their eyes so to speak, from the action in the foreground and to relate it to the wider world beyond - as they are confronted with these multiple perspectives.

Similar ambivalent treatment is accorded by Ostrovsky to the signification of the main referent in the play-the thunderstorm. We have seen already how some of the characters in this tragedy view the storm and respond to it. In many it provokes fear and signifies punishment, retribution or divine intervention beyond the temporal and phenomenal levels. Others, such as Kuligin for instance (who is aligned to Catherine and her perspective in many areas though not in all), view the thunderstorm and lightning positively, as electricity (374 [252]) and as a sign of God's Grace 
(378 [255]): "Now every blade of grass and every flower is rejoicing, and we hide ourselves, as if fearful of some disaster hanging over us! ... [The thunderstorm] is not a sign of wrath, it's God's Grace! Yes, Grace! [...] The beauty of it! [...] See, I'm not afraid.'

In act 4 a whole crowd of people from the town of Kalinin, plus all the main characters in the play, are shown reacting to the thunderstorm brewing and then breaking to the accompaniment of Catherine's confession of guilt. Is her transgression then-the storm brewing inside her-intended to be viewed also in the context of Kuligin's perception of the storm as a sign not of wrath, but of Grace and beauty? Is the storm brewing, both literally and metaphorically in the society depicted, to be regarded as a sign of punishment and doom, or as a sign of release and rejoicing? Is it to be celebrated or feared?

The symbolic function of the river Volga is equally ambiguous. Its waters act as an accompaniment to Catherine's greatest joys and worst suffering. It is a source of escape, of freedom and renewal, yet also of escape through death. As the curtain opens on act 1 Kuligin effusively celebrates the beauty of the Volga, and later proceeds to condemn the inhumanity of the human world (326-27 [210]). By the end of that act, the Half Mad Lady with Two Footmen alludes to the Volga's deep waters as a main-spring of unquenchable fire. In act 3, scene 1 Kuligin again juxtaposes the beauty of the Volga and the natural world with the entrapment and tyranny of merchant society (360-61 [214-15]). The function of Kuligin's speeches can be compared to that of the Chorus in Greek tragedy. Ultimately, Catherine seeks escape and oblivion in the river's dark waters.

The deployment of imagery and symbolism perceived from a variety of perspectives, in addition to literary allusions and songs, elicits an emotional response from the audience; they help build up an atmosphere of inevitability and doom, foreshadowing the tragic ending. Indeed, some dialogues and scenes seem to have little purpose other than the intensification of atmosphere and the foreshadowing of death and destruction. In act 3, scene 2, for instance, leading up to the fateful meeting between Catherine and Boris by the river in the ravine at night, the Russian verb gubit' in its various aspects is used 14 times. It is translated into English in a number of different ways as: ruin; destroy; perish; die; life is not for me; I'm not going to live; death and so on (366-68 [260-61]). 
In addition, synonyms of gubit' are employed by Ostrovsky such as: umirat', umeret', ne zhit', khoronit', kaznit'. The dramatist resorts to alliteration and assonance introducing words such as grekh, grob, gorlo, vrag, grobovaia doska, prognat', poguliat', trogat', and a proliferation of vowel sounds: muka, skuka, toska, bol', pechal'. The relentless repetition of gutturals combined with other imagery signals to the audience Catherine's inevitable doom and suggests that she will be sacrificed for her sins and thereby attain a union with a higher power symbolised by the thunderstorm. The dialogue is both poetic and "operatic" (that is, suitable as a libretto to an opera such as Janacek's Katya Kabanova) because dominant themes and emotions are reiterated in a number of variations for no other reason than to reinforce and elicit the desired emotional responses from the spectator.

\section{The Role of Free Will: "Volia"}

The idea of the will and of free will, which plays such an important role in the dramatic universe of Ostrovsky's Thunder (as well as being such an important category for the modern or contemporary reader), is a concept that appears not to have had a semantic equivalent in ancient Greece. Clifford Leech explains this when he declares that the question of free will "remains a highly dubious one in tragic writing." He then admits, however, that "tragedy allows a minimal free will in that a particular act sets off the train of events that leads to disaster, that what follows is beyond human control. ${ }^{32}$ In the more recent researches of Jean-Pierre Vernant it is substantiated that neither in Aristotle's work nor in the language of his times can one find any word to refer to what we call free will:

The idea of a free power of decision remains alien to [Aristotle's] thought. It has no place in his inquiry into the problem of responsible action either in connection with his notion of a choice made with deliberation or of an action accomplished of one's own volition.

This lacuna is an indication of the distance that separates the ancient Greek concept of the agent from the modern one. There are other

${ }^{32}$ Clifford Leech, Tragedy (London: Methuen, 1969), 40. 
"gaps" that are characteristic of the morality of the ancient world: no word that corresponds to our concept of duty, the tenuous place in the system of values held by the notion of responsibility, the vague and indecisive nature of the idea of obligation. Taken all together, they underlie the different orientation of Greek ethics and contemporary moral consciousness. Also, however, and even more profoundly, they reflect the absence, on a psychological level, of an elaborated category of the will, an absence already betrayed linguistically by the lack of any terminology to describe actions stemming from it. ${ }^{33}$

In relation to the concept of the will in Greek tragedy, Vernant notes in his discussion of Sophocles' King Oedipus that, as Oedipus himself declares in committing parricide and incest, neither his person nor his actions were to blame. In reality he himself had done nothing:

Or rather, while he was committing an action, its meaning became reversed without his knowledge and through no fault of his. Legitimate defense turned into parricide; marriage, the consecration of his honor, turned into incest. Although innocent and pure from the point of view of human law, he is guilty and defiled from the point of view of religion. What he has done without knowing it and with no evil intent or criminal volition is, notwithstanding, the most terrible crime against the sacred order that governs human life. ${ }^{34}$

In Ostrovsky's Thunder the category of free will informs the underlying dramatic action. On the linguistic level it is expressed in the Russian term volia which means "freedom" and "will," and which is translated into English in a variety of ways. It is contrasted to nevolia, the term's semantic negation, that is "nonwill" or "non-freedom," meaning "compulsion." This is translated in dictionaries as "slavery," "bondage," "captivity" or "necessity." Already in act 1, the exposition wherein the setting is established, there are over a dozen references to "will" or "freedom" and to "non-freedom" or "compulsion."

However, there is a certain conceptual ambivalence pertaining to the perception of volia within the Russian society depicted in the

\footnotetext{
33 "Intimations of the will in Greek tragedy," in Vernant and Vidal-Naquet (n. 22 above), 59-60.

${ }^{34}$ Ibid., 121.
} 
play. This is because those who possess volia actually abuse it by subjugating others to their will and curtailing their freedom. They are the authoritarian figures of those in power, whether domestic tyrants or capitalist employers such as Mrs. Kabanova or Dikoy, the so-called samodurs, who are the agents of repressive forces in the play. These samodurs impose their will upon those they consider their underlings, whether in the social, economic or psychological sphere. They do so with relish and conviction, certain of the righteousness of their actions, buttressed by the ideology of the Russian Orthodox Church as it is perceived by them.

The tragic heroine Catherine is someone who is acutely conscious of her sense of volition or will. In act 1 she recalls her idyllic free life in her parents' home and compares it with her restricted new life in the household of her mother-in-law, Mrs Kabanova. When her sister-in-law, Barbara, points out to her that the life as described by her is exactly the same in both households, Catherine's incoherent response is: "Yes, but here it's all like something you've got to do (nevolia)" (335 [221]). She feels "stifled" in her new home, "so stifled I could run away. This is the sort of thought that comes to me - if I had my freedom (volia) I'd like to be out now in a boat on the Volga, with singing, or else in a smart three-horse carriage, with my arm around ... "(337 [223]). In the course of her soliloquy in act 2 she alludes three times to the condition of marriage as "bitter bondage" (nevolia) (352-53 [235]). At the time she is holding the forbidden key offered to her to the garden gate that could lead her ostensibly to freedom and a meeting with Boris. In tune with much of the symbolism pervading the play, the lock and key is a traditional metaphor for the representation of male and female genitalia. ${ }^{35}$ Catherine intends to throw the key into the river but thrusts it into her pocket when she thinks she can hear someone coming: "It looks as if that's where Fate wants it to be" (353 [235]). However, her innate honesty compels her to acknowledge that she won't throw away the key, but will see Boris.

Although Aristotle does not (or could not) refer to free will, he does define tragic character in relation to the nature of choice (prohairesis): "Character is the kind of thing which discloses the

35 See Gilman (n. 17 above), 54-55. 
nature of a choice; for this reason speeches in which there is nothing at all which the speaker chooses or avoids do not possess character. ${ }^{.36}$ The choices that Catherine makes should be seen in the context of the complex interrelationship between her moral capacity and the female social role that is articulated in her choices.

Other characters in Thunder hold distinct notions of duty and obligation inherent in the morality of the world depicted in the play. Thus Catherine's husband Tikhon subjugates his will to that of his mother, who is the head of the household. His behaviour is bound by the notions of morality imparted by his family and its world of religious custom and tradition. He repeatedly reassures his mother that he is following her wishes (volia): "You may think what you like, you always have your own way (volia)" (332 [219]). "I don't want to live my own life (volia). How could I live my own life (volia)? (332 [219]) He seeks solace from his oppressive life in drinking. Boris, the "outsider" from Moscow, who is financially dependent on his uncle Dikoy, in whose household he lives and for whom he works, is also aware that he has no free power of decision or choice in matters relating to his own life. Boris has a sister dependent on him. He describes his life as being one of "slavery" (nevolia) (323 [222]) and his situation is perceived as one of victimage (zhertva) (321 [210]). Once his relationship with Catherine becomes common knowledge Dikoy sends him away to work in Siberia.

The category of the "will" in Thunder is bound up with a cluster of images associated with freedom on the one hand, and with lack of freedom on the other. Thus images of flying, movement and the River Volga are associated with freedom, while confinement, walls, locks and gates are associated with a lack of freedom. The longing or quest for freedom forms a sub-text in the play. Paradoxically, only death will give Catherine the freedom she so desires.

\section{Aristotle's Poetics and Ostrovsky's Thunder}

\footnotetext{
${ }^{36}$ Aristotle, Poetics, trans. and intro. Malcolm Heath (Harmondsworth: Penguin, 1996), 12; see also xviii, 10 and 11. Hereafter all references to Poetics will be included in brackets as page numbers in Heath's translation.
} 
Ostrovsky was familiar with Aristotle's concept of tragedy as set out in his Poetics. The text had influenced the formation of Russian aesthetic thought from the second half of the eighteenth century right up until the composition of Thunder in the late 1850s. The Poetics had been initially popularised in Russia in works such as those of V. K. Trediakovsky's Mnenie o nachale poesii (Belief about the origins of poetics) in 1752, the German dramatist G. E. Lessing in Russian translation in 1767 (Hamburg Dramaturgy), and S. P. Shevyrev in his Teoriia poesii $v$ istoricheskom razvitii of 1836 (A theory of poetics in its historical development). In 1854 one of Russia's leading critics N. G. Chernyshevsky devoted a special article to an analysis of Aristotle's Poetics that was widely read and discussed at the time ("About Poetics: The Work of Aristotle"). ${ }^{37}$ This took place only four years prior to Ostrovsky's composition of Thunder. Passages from the Poetics were cited in the widely used educational texts on literature of the time.

Aristotle's understanding of tragedy as set out in his Poetics has been traditionally held up as a measure of what constitutes "real" tragedy. Ostrovsky's tragedy Thunder can be seen to follow only some aspects of Aristotle's concept of tragedy, departing from it in other areas. This does not mean that it is therefore any less of a tragedy. At the time when he was writing Thunder Ostrovsky's view of tragedy had become grounded also in the Shakespearean tradition. In fact, Ostrovsky is known as a translator of Shakespeare into Russian. Curiously, at the height of his career Ostrovsky was seen by some critics as being the "Russian Shakespeare." In Thunder Ostrovsky dispenses with many of Aristotle's procedural principles of tragedy, just as Shakespeare had done necessarily and as a matter of historical process some centuries earlier. Like Shakespeare he combines the tragic with the comic and includes four comic scenes; there are some subplots in addition to the main plot that involves the tragic heroine Catherine;

37 This review was first published in Otechestvennye Zapiski (Notes of the Fatherland), 1854, vol. 96, no. 9. It was written following the appearance in 1854 of a Russian translation by B. Ordynsky of the Poetics of Aristotle. For an English translation see N. G. Chernyshevsky, "The Poetics of Aristotle," in Selected Philosophical Essays (Moscow: Foreign Languages Publishing House, 1953), 423-53. In his commentary Chernyshevsky states that the Poetics of Aristotle, in the form that work has come down to posterity, is not complete. Subsequent research confirmed this. 
not all characters are directly involved in the main plot and a number of them do not appear in any scenes with Catherine and are not even directly acquainted with her; the action extends over a fortnight or so and takes place in several locations.

One particular element of tragedy given primacy by Aristotle in his Poetics, namely the primacy of plot, the belief that tragedy was not an imitation of persons, but of actions and of life (10 and 11), was an element that found a special resonance in Russia. The "imitation of life" became the most important requirement and turned almost into a slogan. It became absorbed into the progressive trend of the time towards realism, a trend that was to reach its height in Russia following the Romantic period of the first third of the nineteenth century. Aristotle was perceived as having promoted a theory of art aligned to realism, by Chernyshevsky in his 1854 interpretation of the Poetics of Aristotle among others. Ostrovsky was familiar with Greek tragedy and had even translated some of the classical repertoire into Russian.

Aristotle's requirement of thought or reasoning as a component of a character's or an agent's speech (used to argue a case or put forward an opinion) was a further element of tragedy widely adopted in Russia. It was recognised that realism could be purposeful and in Russia it became aligned to the expository trend in drama and literature; some of Ostrovsky's plays were seen to be in this category, that is they served to expose dominant forms of culture and discourse and to contest these ideologies and forms. In Thunder, thought or reasoning becomes the chief element in the speeches of Kuligin, the function of which is to explain, comment on and thus expose the society and action depicted in the play. His speeches have also been compared to those of a Greek Chorus, for he takes little direct part in the action, but appears again and again to comment on it as it unfolds. His name was chosen by Ostrovsky to evoke that of a famous self-taught craftsman of earlier times, though the name also carries symbolic overtones of a brighter future for the Russian people. Kuligin opens the play by reciting some poetry about the beauty of nature spread out before him (and the audience) with a view of the River Volga and the surrounding landscape in the distance. He contrasts the beauty of the natural world with that of the human world representing dominant merchant society with its oppression and brutality, its abuse of the weak and powerless (323-25; 326-27 [210-16]). 
Aristotle also emphasises the universality of art, saying that poetry is more philosophical and more serious than history: "Poetry tends to express universals, and history particulars" (16). Ostrovsky's Thunder, in addition to being culturally specific to pre-Emancipation Russia, also expresses universal truths relating to the concepts of freedom and will (volia). Each character has an individual and different conception of freedom. As marginal members of a society that is dramatised as undergoing change, with its residual and emergent cultural shifts and forms, each character seeking freedom is set in opposition to the dominant forms of discourse. The tragic heroine Catherine epitomises this quest for freedom, having a special awareness of it and finding her life within her husband's extended merchant family stifling and a "bitter bondage" (nevolia) (337, 352-53 [223, 235]). We have already discussed how her longing for freedom frequently takes a kinetic form of expression. In line with the ambivalent conceptual fabric of the play, Catherine recognises that only death will give her the freedom she so desires as she seeks oblivion in the River Volga (351-52 [234-35]). ${ }^{38}$

Tragedy is seen by Aristotle as having six component parts that determine its quality: "plot, character, diction, reasoning, spectacle and lyric poetry" (11). Of these, plot and character are the most crucial elements discussed by him in some detail. According to Aristotle's central definition, "[t]ragedy is an imitation of an action that is admirable, complete, and possesses magnitude; in language made pleasurable, each of its species separated in different parts; performed by actors, not through narration; effecting through pity and fear the purification (catharsis) of such emotions" (10). The latter component of tragedy is very much in evidence in Thunder. Catherine's anguish and humiliation on the one hand and the helplessness of Tikhon and Boris in the face of her suffering on the other, produce the expected cathartic purification of the spectator's emotions. Aristotle singles out suffering as being the third most important component of a plot, the first two being "reversal" and "recognition." "Suffering is an action that involves destruction or pain" (19), while a complex plot, one in which the change of fortune involves "reversal" or "recognition" or both, "will involve pity and fear." The kind of tragic character seen undergoing a

${ }^{38}$ Peace (n. 4 above): 99-110. 
change from good fortune to bad fortune (20 and 21) should not be wholly good or decent, nor wholly depraved or wicked: "We are left, therefore, with the person intermediate between these. This is the sort of person who is not outstanding in moral excellence or justice; on the other hand, the change to bad fortune which he undergoes is not due to any moral defect or depravity, but to an error of some kind" (21). Catherine could be said to fit into these expectations of Aristotle's regarding the moral character of the tragic figure. Catherine's fall from grace and the audience's response to her tragic fate are adumbrated in the fates of Tikhon and Boris. The latter rails hopelessly against his fate: "You wicked cruel monsters! Oh, if I had the strength!" (389 [263]). His words are echoed by Tikhon's cry shortly afterwards as he laments over Catherine's dead body: "It's well for you Kate! But why am I left in the world to live and suffer!" (392 [265]). It can be argued that the fates of the two men are even more tragic than that of Catherine. All three are caught in the turbulence of a society resisting change, although it is only Catherine who is actually pulled down and destroyed as such. This is due to her special qualities of character and spirit, which the others lack as discussed above. The malevolence of gods that exact their rights or the arbitrariness of evil in earlier tragedies can be said to continue in Thunder in the form of one particular view of the elemental thunderstorm seeking retribution and giving license to darkness and chaos.

Catherine appears to the audience as a solitary figure caught in the midst of an almost cosmic storm. Though apparently an ordinary merchant girl, Catherine embodies a quest for perfection, renewal and the Ideal. The insoluble conflict between Catherine's longing for the Ideal and the limitations placed on her by reality lead to her suffering and death. The external thunderstorm which manifests itself during the total action as a sign of both impending doom, and of release and renewal, finds its reflection in the inner turmoil of Catherine's mind. Catherine is able to stand up to her oppressors before she feels guilty and vilified for grievous sin, but having recognised this, she has no escape from her inner mind which torments her. She is unable to reconcile her inner conflict and high ideals with the image of herself in a state of fall. Her spiritual self is disturbed by her declared moral failure and her conscience destroys her; the Absolute for which she longs destroys her when she cannot attain it. It is symbolised by the thunderstorm, 
a great power like God. Her suffering, expressed to the accompaniment of thunder and lightening, evokes the audience's pity and fear. It separates her as a tragic heroine from the rest of the merchant society represented in the play and ennobles her. It is this essential nobility, directness and goodness that contributes to her downfall - a "fatal flaw" in her character that makes her unable to conform to the codes of conduct and dead dogma of the merchant milieu. Her death in the River Volga, River of Life, a symbol of freedom and renewal is a further sign of the ambiguity present at all levels of the play, for in death she merges with nature and the surrounding landscape as she had imagined in her reveries (352 [235]), and breaks free, achieving the absolute freedom she had so desired. It is fitting that it is Kuligin, who has been aligned to her by means of imagery, by the lyrical digressions wherein he addresses nature and by the fact that he too is oppressed and a victim of the society depicted, who now carries her body from the waters of the Volga and places it in front of the crowd that has gathered: "There's your Catherine for you. You can do what you like with her now. Her body is here, take it, but her soul is not yours now; it is now before the Judge, Who is more merciful than ye. (Lays her down on the ground and runs off)" (392 [265]).

The conflict between necessity and freedom, reality and the Ideal exemplified on a personal level in Catherine's tragedy mirrors the wider conflict within Russian culture with its idea of "Holy Russia" and the limitations placed on it by the necessities of temporal power. 